Article original

Animal production

\title{
Effect of Garcinia kola seed Meal on Egg Quality of the African Catfish (Clarias gariepinus) (Burchell) Broodstock
}

\author{
Adekunle Ayokanmi DADA and Blessing Ebekhirire EBHODAGHE \\ Department of Fisheries and Aquaculture Technology, Federal University of Technology, P.M.B. 704, Akure, Ondo state, \\ Nigeria \\ Correspondence author, e-mail: dadaayokanmi@gmail.com
}

\begin{abstract}
A 56-day study was undertaken to evaluate the effects of $G$. kola (Bitter kola) powder on egg quality in African catfish, $C$. gariepinus broodstocks. Catfish broodstocks (mean weight, $911.25 \pm 1.77 \mathrm{~g}$ ) were randomly distributed into concrete tanks $(2 \times 2 \times 1.2 \mathrm{~m})$ at ten fish/tank in triplicates. Five diets designated as diets D1 to D5 with $40 \%$ crude protein containing 0 , $50,100,150$ and $200 \mathrm{~g} / \mathrm{kg}$ of $\mathrm{G}$. kola seeds powder in the feed were formulated and added to the tanks to give $3 \%$ of body weight per day. Fecundity, Percentage fertilization, hatching rate and egg size (diameter) of $C$. gariepinus were investigated. The fish fed diet D5 $(200 \mathrm{~g} / \mathrm{kg})$ had higher oocyte diameter but not significantly different $(p>0.05)$ from those of the fish fed the other diets. However, the egg diameter was largest in the group of fish fed diet diet supplemented with 200 $\mathrm{g} / \mathrm{kg}$ G. kola seed powder (D5) and this has negative effect on the fertilization of the eggs. Significantly higher $(p<0.05)$ egg fertilization and hatching was recorded in the fish fed diets D4 $(150 \mathrm{~g} / \mathrm{kg})$ than for the fish fed the other diets. The results showed that as the level of inclusion of $G$. kola seed powder was increased, the percentage of eggs fertilized increased, except when the fish were fed diet D5 where a sharp decrease was recorded. Survival of fish after the 56 days experimental trial range from $88 \%$ to $100 \%$ and was not related to the $G$. kola seed powder inclusion in the diet. The result of this study shows that $G$. kola seed meal affects the fecundity, hatching rate and percentage survival of $C$. gariepinus and has a potential pro-fertility property which can be exploited in fish seeds production.

Key words: Garcinia kola, fecundity, percentage fertilization, percentage hatchabilty, Clarias gariepinus
\end{abstract}

\section{INTRODUCTION}

Fish is one of the cheapest sources of animal and it is being used increasingly to correct protein deficiency in human diets in the tropics. According to Fasakin and Aberejo [1] and Azam et al. [2], consumption of fish provides an important nutrient to a large number of people worldwide and thus makes a very significant contribution to human and animal nutrition. Unlike protein supplies which are from terrestrial sources, which are derived mainly from livestock farming, fish supplies are heavily reliant on natural sources.

Capture fisheries and aquaculture supplied the world with about 106 million tonnes of fish in 2004 and aquaculture accounted for 43 percent [3]. Hunger and malnutrition remain amongst the most devastating problems facing the world poor and needy [3]. About 80 to 90 million people have to be fed yearly and most of them are in the developing countries. The most reliable source of protein for many is fish, yet millions of people who depend on fish are faced daily with the fear of food shortage [4]. With the population of Nigeria on the rise, there is a corresponding demand for fish consumption [5]. Thus, there is the need for a suitable method of fish seeds production to meet the increasing demand for food. In view of this, medicinal plants that can enhance the fertility of broodstock fit exactly into this.

Nigeria like most third world countries is not able to meet her animal protein requirement of meat, fish and their respective products and this is traceable to our fish production which has fallen below expectation [6]. Dada and Fagbenro [7] reported that fish plays an important role in the world protein supplies especially in developing countries.

Many fish hatcheries in Nigeria are functioning at low capacity producing only a total of some 30 million fingerlings per year [7]. The total existing capacity could easily be 1 billion fingerlings per year. Rapid growth of the fish farming sector should consider the need to focus on improved broodstock for increase in fish seeds production and control fertility in broodstock. Numerous plants have been used to enhance fertility and modern scientific research has confirmed profertility effects in at least some of the herbs tested 
in animals $[8,9]$. Although the toxicity profile of most medicinal plants have not been thoroughly evaluated, it is generally accepted that medicine derive from plant products are safer than their synthetic counterparts [10]. There is dearth of literature on the use of $G$. kola seeds powder as fertility enhancer in fish.

The need for pro-fertility agents in fish with possible minimal side effects, availability, acceptability and affordability informed the evaluation of the powder of $G$. kola seeds in female $C$. gariepinus broodstocks because of its medicinal properties.

G. Kola is a popular plant in southern Nigeria with a myriad of medicinal uses in different parts of the world. The bitter kola [G. kola] is a species of flowering plant in the Clusiacean family, the genus is known as Garcinia. It is a perennial crop distributed throughout West and Central Africa and can attain a height of 35- 40 metres. The genus has between 50-300 species of evergreen trees and shrubs [11]. The active constituents of G. kola are biflavonoids, which are potent antioxidants and xanthones and benezophenones [10]. The phenolic compounds have been pharmacologically proven to possess antiinflammatory, anti-microbial, anti-diabetic and antiviral properties [11]. The seeds extract and dry powder of $G$. kola have been formulated into various forms including cream and toothpaste [12]. Probably, the most widespread use of $G$. kola is in the treatment of malignant tumors. The fresh seed and the dry seed powder when chewed are used to prevent or to relieve cough. The seeds when chewed raw are also used in the treatment of bronchitis and throat infections [12].

The extracts of its seed have been credited with aphrodisiac/ fertility in animals and fish $[10,13$, 14]. Administration of $G$. kola seed extracts improved growth performance in C. gariepinus broodfish [15] which was attributed to the antioxidant and antibiotics properties or its constituents. It is therefore not out of place to expect a similar effect on fish. This method of enhancing fertility in fish could be easier to adopt by poor fish farmers since G. kola seeds are available all year round in the tropics and subtropical regions.

Development of fish seeds production has been identified as a rational way of augmenting the dwindling fish supply from the capture fisheries [16]. In order to adequately provide fish in the required quantities at a reasonable price to
Nigerians, there is a need for adequate brood stock management for fish seeds production.

The catfish, C. gariepinus is the most important fish species cultured in Nigeria [17]. This species has shown considerable potential as a fish suitable for use in intensive aquaculture and the fingerlings of this fish are widely produced in Nigeria. This fish grows rapidly and it is disease and stress resistant and highly productive in polyculture with many fish species [17].

The dearth of information on the use of G. kola seeds powder as fertility enhancer in fish and the need to establish the efficacy of $G$. kola seeds powder as pro-fertility agents in female $C$. gariepinus broodstocks informed this study with a view of recommending strategies to fish hatchery operators. The objectives of this study were to investigate the effects of varying dietary supplementation of $G$. kola seeds meal on the fecundity, oocyte diameter, fertilization, hatchability and survival of hatchlings of $C$. gariepinus.

\section{MATERIALS AND METHODS}

The experiment was carried out in the research farm of the Department of Fisheries and Aquaculture Technology, Federal University of Technology, Akure, Ondo State, Nigeria. The experiment consisted of five treatments with each representing different inclusion level of $G$. kola Meal. There were three replicates per treatment. The graded level of $G$. kola seeds powder used were $0.00 \mathrm{mg} / \mathrm{kg}$ feed, $50 \mathrm{~g} / \mathrm{kg}$ feed, $100 \mathrm{~g} / \mathrm{kg}$ feed, $150 \mathrm{~g} / \mathrm{kg}$ feed and $200 \mathrm{~g} / \mathrm{kg}$ feed in the treatment respectively designated as diets D1 to D5.

\section{Plants materials}

The plant materials, G. kola seeds were obtained from a local market in Akure, Ondo State, Nigeria. The outer coats were removed and the seeds sundried. The dried seeds were ground into fine powder. Fish feeds were prepared by mixing the powder with basal feed of $40 \%$ crude protein, based on the formulation defined for African Catfish by Fagbenro and Adebayo (19) to give 50, 100,150 and $200 \mathrm{~g} / \mathrm{kg}$ of the powder in the basal feed designated as diets D1 to D5. Proximate analysis of the $G$. kola seeds as shown in table 1 was carried out as described by AOAC [18]. 
Table 1: Proximate Composition of Garcinia kola seeds

\begin{tabular}{ll}
\hline Nutrient content & Composition (\% DM) \\
\hline Moisture & 4.30 \\
Ash & 3.45 \\
& \\
Crude lipid & 2.43 \\
Crude protein & 4.30 \\
Crude fiber & 11.33 \\
NFE* $^{\text {NF }}$ & 74.19 \\
\hline
\end{tabular}

*Hydrolysable carbohydrate content computed as Nitrogen Free Extract (NFE)

*Determined using standard methods [AOAC 1997). All samples were analysed in triplicates.

**Vitamin premix - A Pfizer livestock product containing the following per $\mathrm{kg}$ of feed: $A=4500 \mathrm{I} . \mathrm{U}, \mathrm{D}=11252$ I.U, $E=71$ I.U, $K_{3}=2 \mathrm{mg}, B_{12}=0.015 \mathrm{mg}$, panthothenic acid $=5 \mathrm{mg}$, nicotinic acid $=14 \mathrm{mg}$, folic acid $=0.4 \mathrm{mg}$, biotin $=0.04 \mathrm{mg}$, choline $=150 \mathrm{mg}$, cobalt $=0.2 \mathrm{mg}$, copper $=4.5 \mathrm{mg}$, iron $=21 \mathrm{mg}$, manganese $=20 \mathrm{mg}$, iodine $=0.6 \mathrm{mg}$, selenium $=2.2 \mathrm{mg}$, zinc $=20 \mathrm{mg}$, antioxidant $=2 \mathrm{mg}$

${ }^{* \star *}$ NFE $=$ Nitrogen - free Extract $=100$ (Crude protein, Crude fibre, Lipid content, Moisture content, Ash)

\section{Collection and Acclimatization of Experimental Fish}

One hundred and fifty female Clarias gariepinus broodfish (mean weight, $911.25 \pm 1.77 \mathrm{~g}$ ) obtained from a fish farm in Akure, Ondo state, Nigeria were used for this investigation. The broodfish were acclimated to laboratory conditions for 14 days before being randomly divided into three equal experimental groups (ten fish each treatment, three replicate/tank) representing five nutritional treatments. One group served as control and four groups represented the G. kola seed meal tested. The experimental fish were weighted every 15 days in order to adjust the daily feed rate which was $3 \%$ of the total biomass at two times/ day (800 and $1800 \mathrm{hr}$ ) for 56 days.

\section{Formulation of Experimental Diets}

The plant materials, $G$. kola seeds were obtained from a local market in Akure, Ondo State, Nigeria. The outer coats were removed and the seed sun dried. The dried seed were grounded into fine powder. 50, 100, 150 and $200 \mathrm{~g} / \mathrm{kg}$ measured out and mixed with basal feed of $40 \%$ crude protein based on the formulation defined for African catfish: C. gariepinus [19].
Five isonitrogenous diets were formulated from practical ingredients (Table 2) where the control basal diet was without $G$. kola seed meal and the other diets were supplemented by $50,100,150$ and $200 \mathrm{~g} / \mathrm{kg}$ of $\mathrm{G}$. kola seed meal respectively. The experimental diets were formulated to contain almost $40 \%$ crude protein. All dietary ingredients were weighed with a weighing top load balance (Metler Toledo, PB 8001 London). The ingredients were ground to a small particle size. Ingredients including vitamin premix and $G$. kola seeds meal were thoroughly mixed in a Hobbart A- 2007 pelleting and mixing machine (Hobart Ltd London, England) to obtain a homogenous mass, cassava starch was added as a binder. The resultant mash was then pressed without steam through a mixer with $0.9 \mathrm{~mm}$ die pore size attached to the

Hobart pelleting machine. The produced pellets were dried at room temperature and kept frozen until the beginning of the experiment.

\section{Experimental design}

Water was sourced from an adjacent fish pond using 1.5HP pump and the tanks were filled to a depth of $0.6 \mathrm{~m}$. Ten females $C$. gariepinus broodstock were stocked into each tank, with three replications per treatment. The experimental fish were weighted every 15 days in order to adjust the daily feed rate which was $3 \%$ of the total biomass at two times/ day (800 and $1800 \mathrm{hr}$ ) for 56 days.

All fish were removed from each concrete tank every week and batch-weighed.

\section{Reproductive performance}

At the end of the feeding trials, six females randomly selected per dietary treatment were weighed, killed and dissected to remove the ovaries. Fecundity estimation was done using gravimetric sub-sampling (wet method) as described by Bagenal [20]. The ovaries were carefully weighed after removing excess water on filter paper and counted the number of eggs per $g$ and then calculated the total number of eggs. The total number of eggs per ovary was derived by multiplication by the factor; total weight/10 g. Six fresh eggs randomly selected per dietary treatment were used for egg diameter $(\mathrm{mm})$ measurement. For the pear-shaped eggs, the mean diameter of the long and short axes was taken as the diameter of the oocyte [21]. Data on egg diameter in conjuction with the Percentage 
fertilization and percentage egg hatching were used to assess the egg quality.

\section{Determination of fertilization rate}

For calculating percentage fertilization, a sample of about 30 eggs from each replicate of each treatment were carefully taken on Petri dish and $0.1 \mathrm{ml}$ of milt was measured with a plastic syringe and used to fertilize each replicate of the treatment and the number of fertilized and unfertilized eggs were counted under a microscope (40 times magnification). The percentage of eggs fertilized as well as the percentage number of eggs hatched and percentage survival were computed according to the method described by Ayinla [21]:

$\%$ Egg fertilized = Number of eggs incubated number of opaque eggs / Total number of eggs incubated 100

$\%$ egg hatching = Number of whitish broken eggs 1 Number of eggs fertilized 100

$\%$ Survival $=$ Number of hatchlings alive up to larvae stage / Total number of hatchlings $\times 100$

\section{Determination of indices of growth}

At the end of the experimental period, weight gain of the fish was calculated using the following equation:

WG = Final average weight $(\mathrm{g})$ - Initial average weight $(g)$

\section{Water quality parameters}

Water quality parameters such as temperature, $\mathrm{pH}$ and dissolved oxygen concentration were monitored weekly throughout the study using mercury-in-glass thermometer, pH meter (Hanna H198106 model) and dissolved oxygen meter (JPP-607 model) as described by APHA [22].

\section{Statistical analysis}

The values are recorded as mean \pm standard deviation. The statistical significance of difference in the mean and standard deviation $(P<0.05)$ was analyzed by one-way ANOVA test to test for significant differences between the various treatment means obtained using the SPSS 15. Duncan's multiple range was used to determine which pairs of the treatment means differed significantly [23]. Differences were considered significant at $\mathrm{P}<0.05$.

Table 2: Ingredient and proximate composition of experimental diets (g)

\begin{tabular}{llllll}
\hline & \multicolumn{3}{c}{ Treatments } \\
\cline { 2 - 5 } Ingredients & $\begin{array}{l}\text { D1 } \\
\text { (control) }\end{array}$ & D2 & D3 & D4 & D5 \\
\cline { 2 - 5 } Fish meal (65 \%) & 250 & 250 & 250 & 250 & 250 \\
Yellow maize & 150 & 150 & 150 & 150 & 150 \\
Soy bean meal (45 \% Cp) & 350 & 350 & 350 & 350 & 350 \\
Blood meal (85 \% Cp) & 100 & 100 & 100 & 100 & 100 \\
Fish oil & 60 & 60 & 60 & 60 & 60 \\
Vegetable oil & 40 & 40 & 40 & 40 & 40 \\
Vitamin premix & 30 & 30 & 30 & 30 & 30 \\
Binder (starch) & 20 & 20 & 20 & 20 & 20 \\
G. kola seed meal (g kg ${ }^{-1}$ ) & 0 & 50 & 100 & 150 & 200 \\
Proximate composition (\% DM) & & & & & \\
Moisture & 8.05 & 7.10 & 8.18 & 8.14 & 8.20 \\
Crude protein & 41.30 & 40.30 & 38.70 & 38.70 & 39.80 \\
Crude lipid & 13.26 & 13.74 & 13.75 & 13.75 & 14.26 \\
Crude fibre & 6.24 & 5.88 & 6.12 & 5.12 & 4.35 \\
Ash & 12.15 & 12.06 & 12.00 & 11.88 & 10.88 \\
NFE & 19.00 & 19.92 & 21.25 & 22.41 & 23.11 \\
\hline
\end{tabular}




\section{RESULTS}

Data on weight gain and reproductive performance of female $C$. gariepinus fed on dietary $G$. kola seed meal are presented in table 3. The fecundity of the female brood fish fed diets D2, D3, D4 and D5 [28000, 38810, 29750 and 34830] was significantly higher $[p<0.05]$ than what was obtained from the ovary of fish fed the control diet D1 [Table 3]. The fish fed the diet D5 had higher oocyte diameter but not significantly different [p>0.05] from those of the fish fed the other diets [Table 3]. Survival of fish after the 56 days experimental trial range from $88 \%$ to $100 \%$ and was not related to the $G$. kola seed powder inclusion in the diet.

Figure 1 shows the percentage fertilization, hatching rate and percentage survival of $C$. gariepinus broodfish fed $G$. kola seed diet. Significantly higher $(p<0.05)$ egg fertilization and hatching was recorded for the fish fed diets D4 than for the fish fed the other diets [Figure 1]. The results showed that as the inclusion level of $G$. kola seed powder increased, the percentage egg fertilization increased, except when the fish were fed diet D5 where a sharp decrease was recorded.

The water quality parameters measured varied as follows: temperature, $20.40^{\circ} \mathrm{C}-28.40^{\circ} \mathrm{C}$, dissolved oxygen, 6.10-10.8mg/l and $\mathrm{pH}, 6.99$ - 7.20 [Table 4].

\section{DISCUSSION AND CONCLUSION}

The result of this study shows that $G$. kola seed meal affects the fecundity, hatching rate and percentage survival of $C$. gariepinus. Dada and Ajilore [14] recorded an increase in the fecundity and egg size of $C$. gariepinus fed on ethanol extract of $G$. kola seed diets at different inclusion level. Adesanya et al. [13] reported an increase in the sperm count of wistar rats after treatment with ethanol extract of $G$.kola seed for 6 weeks. The increase in fecundity of $C$. gariepinus in this study could be attributed to the presence of biflavonoid and xanthone in the plant. These compounds are potent anti-oxidants which are capable of increasing the production of eostrogen, the key hormone involved in the production and maturation of eggs in the ovary.

The egg diameter was largest in the group of fish fed diet D5 and this has negative effect on the fertilization of the eggs. Some authors however opined that egg diameter is not a good indicator of egg and larval quality [24]. In this study, the progeny of the brood stocks fed on diets D1 and D4 survived better than the ones placed on other diets. Since most of the losses in hatchery are recorded at the critical transitional period of moving from endogenous feeding to exogenous feeding, any effort made to improve the quality of the egg will surely equip the fry for survival [25].Other studies in man has shown that G. kola seed powder improved fertility in male, especially sperm characteristics. The significantly higher $(p<0.05)$ percentage fertilization and hatching observed in the fish fed the diet D4 agrees with Adewumi et al. [26] who reported that $C$. gariepinus broodstock fed differently heated soybean based diets had smaller eggs and produced lower hatching rates and larval survivals than the control fish which were fed on fish meal based diet. Sule and Adikwu [27] also reported that species of the genus Clarias with larger eggs also have a higher viability and endurance to starvation than those with smaller eggs and that larger female catfish produce larger eggs.

Oluyemi et al. [10] recorded an increased in the diameter of seminiferous tubule of male wistar rats treated with ethanol extract of $G$. kola seed while Akpantah et al. [28] also reported increased in the peripheral testosterone levels in wistar rats treated with the ethanol extract of $G$. kola seed. The dissolved oxygen, $\mathrm{pH}$ and temperature estimated during the experiment were within the acceptable range recommended for catfishes [29].

In conclusion, dietary G. kola seed meal, which improves the reproductive performance of cultured African catfish, C. gariepinus is useful and reliable method for propagating seedling production and rearing strategy. This study established the efficacy of $G$. kola seeds powder as fertility enhancer in $C$. gariepinus brood stock and should be encouraged as it will minimize the dependence on synthetic drugs as fertility enhancing agents. Therefore, future research should focus on the improvement of seedling production technology for different fish by $G$. kola seed powder, since the main aim of aquaculture is to maximize fish production and this plant has promising pro fertility property which can be exploited in aquaculture 
Table 3: Weight gain, fecundity and egg size of $C$. gariepinus broodstock after treatment (mean $\pm S D$ )

\begin{tabular}{|c|c|c|c|c|c|}
\hline Treatment & $\begin{array}{l}\text { Initial mean weight } \\
\text { (g) }\end{array}$ & $\begin{array}{l}\text { t Final mean weight } \\
(\mathrm{g})\end{array}$ & $\begin{array}{l}\text { Mean weight gain } \\
\text { (g) }\end{array}$ & $\begin{array}{c}\text { Fecundity } \\
(\mathrm{n} 0)\end{array}$ & $\begin{array}{c}\text { Egg Size } \\
\text { (diameter)mm }\end{array}$ \\
\hline D1 & $910 \pm 0.00^{\mathrm{a}}$ & $1092 \pm 22.5^{\mathrm{a}}$ & $182 \pm 26.0^{\mathrm{a}}$ & $22167.5 \pm 9692.5^{a}$ & $1.30 \pm 0.00^{a}$ \\
\hline D2 & $911.5 \pm 1.50 \mathrm{a}$ & $1137.5 \pm 12.5^{b}$ & $226.5 \pm 5.1^{b}$ & $28000 \pm 2500^{b}$ & $1.35 \pm 0.05^{a}$ \\
\hline D3 & $912.5 \pm 2.50^{\mathrm{a}}$ & $1145 \pm 35.0^{b}$ & $232.5 \pm 42.5^{b}$ & $38810 \pm 3890^{c}$ & $1.35 \pm 0.05^{a}$ \\
\hline D4 & $911 \pm 1.00^{a}$ & $1150 \pm 45.0^{\mathrm{b}}$ & $239 \pm 35.5^{b}$ & $29750 \pm 10550^{b}$ & $1.40 \pm 0.00^{a}$ \\
\hline D5 & $912.5 \pm 2.50^{a}$ & $1162.5 \pm 37.0^{b}$ & $250 \pm 35.0^{b}$ & $34830 \pm 21690^{c}$ & $1.55 \pm 0.15^{a}$ \\
\hline
\end{tabular}

Table 4: Summary of water quality parameters from all treatments over 56 days in outdoor concrete ponds.

\begin{tabular}{lccc}
\hline Parameters & Minimum & Maximum & Mean \pm S.D \\
\hline Temperature ${ }^{\circ} \mathrm{C}$ & 26.40 & 28.40 & $27.4 \pm 1.0$ \\
Dissolved oxygen(mg/l) & 6.10 & 10.80 & $8.45 \pm 2.35$ \\
$\mathrm{pH}$ & 6.99 & 7.20 & $7.10 \pm 0.11$ \\
\hline
\end{tabular}

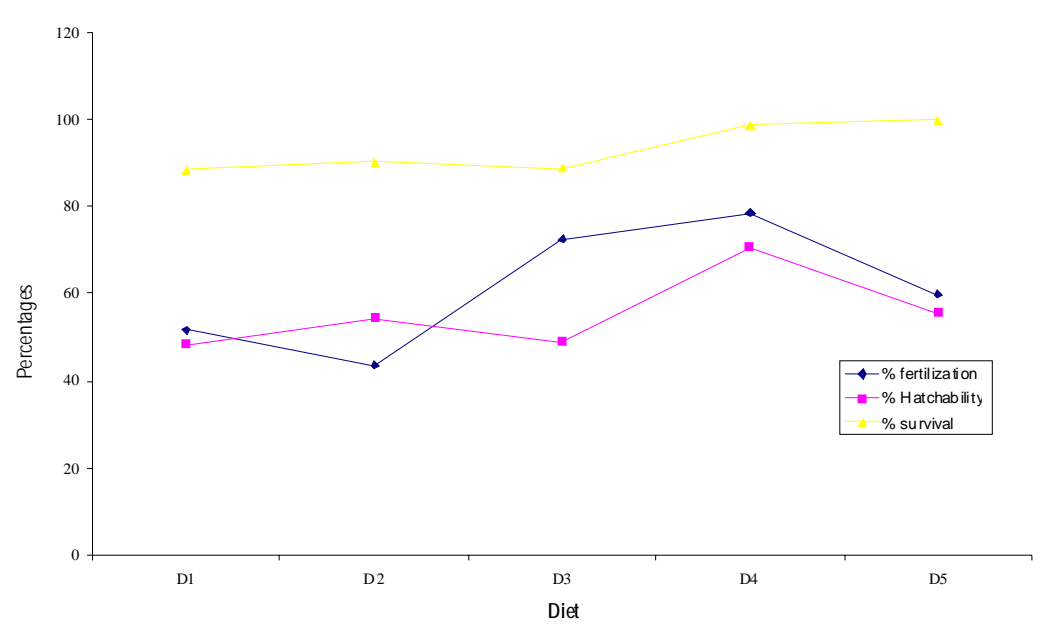

Figure 1: Comparison of Percentage fertilization, Hatchability and Survival of $C$. gariepinus fed with G. kola seed meal 


\section{REFERENCES}

1. Fasakin E.A. and Aberejo B.A. 2002. Effect of some Pulverized plant materials on the developmental. stages of fish beetle, Dermestes Maculatus Degeer in Smoked Catfish (Clarias gariepinus) during storage. Bio Science Technology (85): 173 - 177.

2. Azam, K., Ali, M.Y., Asaduzz Aman, M., Basher, M.Z. and Hossain M.M. 2004. Biochemical assessment of selected fresh fish. Journal of biological sciences (4): 9 - 10.

3. FAO. United Nations Food and Agriculture Organization. 2007. The state of World Fisheries and Aquaculture. FAO, Rome: $142 p$.

4. World fish centre. 2003. Fish an issue for everyone. A concept paper for fish for all summit. 10p.

5. Gabriel V. U., Akinrotimi O. A., Bekibele D.O., Anyanwu P. E. and Onunkwo D.N. 2007. Economic benefit and ecological efficiency of integrated Fish farming in Nigeria. Scientific Research and Essay 2 (8): 302 308.

6. Alatise O.M. 1988. Fish breeding and Fish seed multiplication. Proceeding of the National Fish Farmers Workshop (A. M. Ajana ed.): 117- 132.

7. Dada K and D Fagbenro D. 2008. Catfish fingerlings production in Nigeria. Proceedings of the $4^{\text {th }}$ Annual Conference of School of Agriculture and Agricultural Technology, Federal University of Technology, Akure :107110.

8. Farombi E.O., Akanni 0.0. and Emerole G.0. 2002. Antioxidant and scavenging activities of flavonoid extract (Kolaviron) of Garcinia kola seeds in vitro. Pharm. Biol 40 (2): 107 - 116.

9. Salman J.M. and Adesokan A.A. 2007. Sperm quality of male rats treated with aqueous extracts of Enantia chlorantha stem bark. African Journal of Biotechnology 7(7): $865-867$.

10. Oluyemi K.A., Jimoh O.R., Joisah S.J., Olamide A.A., Omotuyi I.O. and Oyesola T0.2007b. Effect of Crude Ethanolic Extract of Garcinia Cambogia on the Reproductive system of male wistar rats[Rattus noverngicus] African journal of Biotechnology 6 (10):1236-1238.
11. Iwu M.M. 1985. Antihepatotoxic constituents of Garcinia kola seeds. Experimental (4): 699 700

12. Iwu M.W. 1993. Handbook of African Medicinal Plant. CRC Press. Boca Raton. Ann Arbor London. Tokyo:183 - 184.

13. Adesanya O.A., Oluyemi K.A., Omotuyi I.O., Saalu C.L. and SJ Josiah S.J. 2997b . Erythropoietic and Anti- Obesity effects of Garcinia cambogia ( Bitter Kola) in Wistar rats. Biotechnol. Appl. Biochem 46: 69 - 72.

14. Dada A.A. and Ajilore V. 2009. Use of Ethanol extracts of Garcinia Kola seed as fertility enhancer in female catfish Clarias gariepinus. International Journal of fisheries and Aquaculture 1[1]: 005-010.

15. Dada A.A. and Ikuorowo M. 2009. Effects of ethanolic extracts of Garcinia kola seeds on growth and haematology of catfish (Clarias gariepinus) broodstock. African Journal of Agricultural Research 4(4): 344 - 347.

16. F.A.O. 1990. Utilization of tropical food and animal product. FAO food and nutrition. paper 47 FAO Rome pp8-21

17. Ayinla O.A. 2003. Integrated fish farming: Averitable tool for poverty alleviation/hunger eradication in the Niger Delta Region. Procedings of the Fisheries Society of Nigeria, Owerri, Nigeria (Eyo, A.A and Atanda eds.):40-41.

18. A.O.A.C. (Association of Official Analytical Chemists). 1997. In: Cunniff PA (Ed.). Official Methods of Analysis of A.O.A.C. International $16^{\text {th }}$ Edn. Arlington, V.A.1141.

19. Fagbenro O.A. and OT Adebayo O.T. 2005. $A$ review of the animal and aqua feed industries in Nigeria. In: A synthesis of the formulated animal and industry in subSaharan Africa, pp. 25- 36. (Moel, J and Halwart M editors) CIFA Occasional paper No. 26, FAO Rome. 61pp.

20. Bagenal T. 1978. Handbook on Methods of Assessment of Fish Production in Fresh Waters:166- 172.

21. Ayinla O.A. Nutritive and Reproductive performance of Clarias gariepinus (Burchell 1822). Unplished Ph.D Thesis, University of Ibadan, Nigeria. 433p.

22. A.P.H.A.1987. Standard Method for the Examination Water and Wastewater. $17^{\text {th }}$ ed. Washinghton D.C. Pp.1268. 
23. Zar J.H. 1996. Biostatistical analysis. $3^{\text {rd }}$ Edition. Prentice- Hall, Upper Saddle River, New jersey, US: 383Pp.

24. Carillo M., Sanuy S., Prat F., Cerda J., Ramos J., Mananos E. and Bromage N. 1995. Sea Bass (Dicentrachus labrax L). In: Broodstoxk Management and Egg and Larval Quality, (Eds: Bromage and J Roberts), Blackwell Science, Osmead, Oxford: 424Pp.

25. Davy F.B. and Chouinard A. 1980. Induced Breeding in S.E. Asia. The International Development Research Centre. Ottawa, Canada: 1277 - 1285.

26. Adewumi A.A., Olaleye V.F. and Adesulu E.A. 2005. Egg and Sperm Quality of the African Catfish, Clarias gariepinus (Burchell) Broodstock Fed Differently Heated soybean base Diets. Research Journal of Agriculture and Biological Sciences 1(1): 17 - 22.
27. Sule O.D. and Adikwu I.A. 2004. Effect of broodstock size on egg and the African catfish, Clarias gariepinus under laboratory conditions. Journal of Aquatic Science 2004, 19(1): 1 - 4 .

28. Akpantah A.O., Oremosu A.A., Noronhna C.C., Ekanem J.B. and AO Okanlawon A.O. 2005. Effect of Garcinia kola seed extracts on ovulation, Oestrous cycle and foetal development in cyclic female Sprague dawley rat. Nigerian Journal of Physiological Science 20 (1- 2): $58-62$.

29. Viveen W.J., Ritcher C.J.J., Van oordt P.G.W.J., Janseen J.A.L. and EA Huisman E.A. 1985. Practical manual for the Culture of African Catfish. C. gariepinus. Directorate General for Intern. Co- operation. The Hague:93pp. 